\title{
1. Conceptualizing space and place: lessons from geography for the debate on privacy in public
}

\author{
Bert-Jaap Koops and Maša Galič
}

\section{INTRODUCTION}

The debate taking place in the fields of law, philosophy and Science and Technology Studies (among others) about privacy in public focuses on whether and to what extent privacy can, or should be, protected when people move 'in public', that is, 'in public space' or 'in public places'. Many participants in the debate have some intuitive understanding of 'public space', but may not be aware of the rich literature on the concepts of 'space' and 'place' and the analysis of private and public places. When '[s]pace is the everywhere of modern thought' 1 and our historical moment is, above all, the 'epoch of space', ${ }^{2}$ we should make some effort to understand what this thing called space is and what it does, and how the spatial context around us influences our lives-including our privacy expectations when moving around 'in public space'.

We think that the debate on privacy in public can benefit significantly from scholars in various fields acquiring a deeper understanding of how space and place can be conceptualized - and what this conceptualization may mean for the challenges and regulation of privacy in public. Insights from geography that inform us about questions of power related to public space and the relevance of place and space for identity-building are particularly relevant to the debate on privacy in public. Such insights tell

* The research for this chapter was made possible by a grant from the Netherlands Organisation for Scientific Research (NWO), project no. 453-14004.

M. Crang and N. Thrift, 'Introduction' in M. Crang and N. Thrift (eds), Thinking Space (Routledge, 2000) 1.

2 M. Foucault, 'Of Other Spaces' (1986) 16 Diacritics 22. 
us that the common (legal) division of the social world into public and private is not a natural division; rather, it is an expression of power, as is evident, for example, in the ongoing privatization and securitization of public space. The public and the private spheres of life are, as geographers have convincingly argued, interdependent and establish each other. Moreover, geographers have shown how place and identity are closely intertwined in a process of co-production. In today's networked world, the narratives people use to understand themselves in the world, which are constitutive of their identities, are associated with multiple places and movements, and thus they are as equally formed through people's experiences in public places as they are through living at home. Yet the law continues to assume a fixed and clear-cut distinction between private space (carrying a strong reasonable expectation of privacy) and public space (which carries far less reasonable expectation of privacy). Geography's insights should thus inform law, governance and other fields of academic research that are determining the value and level of privacy protection in public space.

In this chapter, we aim to open up key insights from the literature on space and place that are relevant for the debate on privacy in public. In line with this book's theme, the focus is on physical space rather than digital space, although we will make some remarks about the interactions between physical and digital spaces. We draw principally from human geography, as this field occupies a central position in a broader range of disciplines (such as sociology, cultural studies and philosophy) that experienced a 'spatial turn' in the later twentieth century. ${ }^{3}$ We must warn the reader, however, that neither of us is a specialist in geography. Rather, we have studied the literature on space and place from the perspective of legal scholars thinking about current privacy challenges. The result is a chapter that discusses key insights from geographic literature as understood by two outsiders who have benefited from reading this literature. It might be seen as a response to Tim Cresswell (who presents his introduction to the concept of place as 'an offering, from the place of geography, to the wider world'), ${ }^{4}$ showing how the world of regulatory scholarship can benefit from this offering to inform an important contemporary social problem that confronts many academics in nongeographically-informed fields.

3 B. Ward and S. Arias (eds), The Spatial Turn: Interdisciplinary Perspectives (Routledge, 2008).

4 T. Cresswell, Place: An Introduction (2nd edn, Wiley Blackwell, 2015) xii. 
After an introduction to geography, space and place, we discuss several key themes, roughly structured at three levels of analysis (descriptive, constructivist and phenomenological). ${ }^{5}$ This structure serves as a heuristic to discuss the things we find relevant, connected to three major overarching themes (context, power and identity). We do not claim that these themes belong uniquely to any one level of analysis or any single school of thought; for example, structuralists also write about identity, and phenomenologists write about power. We follow themes rather than different analytic frameworks, discussing scholars from different schools within each section. We end by drawing some conclusions for the debate on privacy in public.

\section{A BIRD'S-EYE VIEW OF SPACE AND PLACE IN GEOGRAPHY}

\subsection{Ultrashort History of Geography}

Thinking about space has obvious roots in philosophy. Descartes, for instance, sees space as intrinsically related to the dimensionality of masses (or bodies) in space (the notion of Cartesian space). Newton saw space as an independent, three-dimensional, infinite container for matter. In contrast to these absolute conceptions of space, Leibniz posited that space is fundamentally relational: space does not exist in itself, but rather is the relation between bodies. ${ }^{6}$

Geography emerged in the eighteenth century as a distinct discipline. The field of geography is usually divided into physical geography (the study of the natural environment) and human geography (the study of the cultural or constructed environment). In this chapter, we focus on the latter branch. In the nineteenth and early twentieth centuries, human geography was dominated by regional geographers who tried to capture what makes a certain region of the world special. Around 1960, a positivist school emerged, using quantitative, statistical approaches to geography. While these traditions largely applied a Newtonian conception of space, various approaches arose in the 1970s that can be thought of as 'critical geography', involving a more Leibnizian understanding of space. For instance, behavioural geography looks at how people make places; humanist geography studies people and their condition, approaching

5 Cf. n. 9 above and surrounding text.

6 R.T. Tally, Jr, Spatiality (Routledge, 2013) 27-8. 
geographic concepts through phenomenology or the lens of human experience; and structural or 'radical' approaches study geography using, for example, Marxist or feminist theory. These are followed by postmodern and post-structural approaches. ${ }^{7}$ Recently, an 'intellectual project' of legal geography appears to be emerging, which researches the interconnections between law and spatiality, especially their reciprocal construction. $^{8}$

As in most disciplines, approaches or schools usually do not replace each other, but continue to exist with their own traditions, thinking and advances, and sometimes combine into new approaches. Although geography is therefore very diverse, three basic approaches can be distinguished at different levels of analysing place: (1) a descriptive approach (dominant in regional studies, with a 'neutral', Newtonian conception of space); (2) a social-constructionist approach (dominant in 'radical' and post-structural streams, focusing on how place is constructed under a variety of structural conditions); and (3) a phenomenological approach (dominant in humanist and behavioural streams, 'seeking to define the essence of human existence' in terms of being 'in-place', and more interested in 'Place' than in 'places'). ${ }^{9}$ Of course, these levels of analysis often overlap, but the classification provides a useful heuristic to structure our discussion of the varied insights that geography can bring to academic thinking in law and governance. However, before diving directly into this discussion, we outline the basic concepts of 'space' and 'place' in the following section.

\subsection{Duality of Space and Place}

In popular speech (and in many academic disciplines where scholars are unaware of geographic theory, including law), the terms 'space' and 'place' are often used interchangeably. One important contribution from geography is a more precise meaning of each of these terms. Although the conceptual debate is ongoing, there is a rough consensus that space is a more abstract concept than place. ${ }^{10}$ 'Space' is associated with the

7 P. Hubbard and R. Kitchin, 'Introduction: Why Key Thinkers?' in P. Hubbard and R. Kitchin (eds), Key Thinkers on Space and Place (2nd edn, Sage, 2011) 12.

8 I. Braverman, N. Blomley, D. Delaney and A. Kedar, 'Introduction' in I. Braverman et al. (eds), The Expanding Spaces of Law: A Timely Legal Geography (Stanford University Press, 2014).

9 Cresswell (n. 4) 56.

$10 \quad$ Ibid. 15. 
Newtonian, container-like conception of the physical world, in which matter is located somewhere along three dimensions, ${ }^{11}$ a conception that resonates with our intuitive understanding of space (or place). Combining the structuralist insight that space is socially produced and not given ${ }^{12}$ and the humanist insight that "people do not live in a framework of geometric relationships but in a world of meaning', ${ }^{13}$ it becomes clear that spaces often function in specific ways, with distinct characteristics and meaning in particular contexts. Then, space becomes place. Hence, 'the most straightforward and common definition of place' is: 'a meaningful location'. ${ }^{14}$ Interestingly, the distinction between space and place thus mirrors the distinction between data and information, where 'information' is commonly conceptualized as 'meaningful data'. ${ }^{15}$

As Tuan has shown, the concepts of space and place can be correlated with movement and stability: a space can become a place when we stand still and observe, while place is 'essentially a static concept' and can, in that sense, also be defined as 'whatever stable object catches our attention'. ${ }^{16}$ As places are spaces we (come to) know and value, they form a basic condition of life:

From the security and stability of place we are aware of the openness, freedom and threat of space, and vice versa. Furthermore, if we think of space as that which allows movement, then place is pause; each pause in movement makes it possible for location to be transformed into place. ${ }^{17}$

One can thus see the home as the ideal type of place: the most meaningful, valued, stable and safe space a person might inhabit. In contrast, public space is often the space for moving between places, such as commuting from home to the office (although parts of public space are, of course, also meaningful, for instance, as places for politics or of private memory, see 4.1 and 5.1 below). However, place and space are not discrete, mutually exclusive concepts; rather, they form a spectrum

\footnotetext{
11 Hubbard and Kitchin (n. 7) 4.

12 Seminally, H. Lefebvre, The Production of Space (Blackwell, 1991). Cf. 4 below.

13 Hubbard and Kitchin (n. 7) 6, referring to Yi-Fu Tuan's central contribution, e.g. in Yi-Fu Tuan, Space and Place: The Perspective of Experience (University of Minnesota Press, 1977).

14 Cresswell (n. 4) 12; similarly I. Altman and E.H. Zube (eds), Public Places and Spaces (Plenum Press, 1989) 2.

15 L. Floridi, Information: A Very Short Introduction (Oxford University Press, 2010) 21-2.

16 Tuan (n. 13) 179 and 161.

17 Ibid. 6.
} 
with place at one end and space at the other, which is 'simultaneously a continuum linking experience to abstraction'. ${ }^{18}$

Space and place are intrinsically related concepts: they constitute each other. A place takes meaning from the spaces outside it, and spaces are relevant in relation to the places they surround. ${ }^{19}$ In logical terms, space would seem to be the primal concept: you first need a space that you can then fill with meaning, in order to get a place; for example, the act of giving a name to a space (such as New Amsterdam or The Hebrides) is often a key step in creating a place. In existential terms, however, place is the primal concept: ${ }^{20}$ we exist only through being-in-the-world, as argued by Heidegger. Being is more than just being in place as a container: it is Dasein: being there or being in. ${ }^{21}$ For humans, this implies that dwelling, involving a continuity between a person and a place, is fundamental to human existence: '[d]welling is the manner in which mortals are on the earth'. ${ }^{22}$ Heidegger's 'claim for the existential importance of residing with things in a sustained and absorbed fashion' ${ }^{23}$ reinforces the notion of place, and particularly the dwelling (both the building and the activity), as a stable, safe, fixed place. This may be 'romantic and nostalgic', ${ }^{24}$ but still has value in seeing human existence as fundamentally residing near things, a conception that-in a world where things are increasingly mobile - can imply, in contrast to Tuan's association of place with stasis, that place can also be dynamic and mobile (see 5.2 below).

From the above, it becomes clear that place has two main components: materiality and meaning. ${ }^{25}$ The materiality of a place consists of two aspects: location, i.e. being situated at certain coordinates on Earth (or elsewhere) (which need not be fixed: ships and camps can also be places);26 and locale, i.e. the 'material setting for social relations', which is the shape or form that a place takes. ${ }^{27}$ The meaning of a place is the 'subjective and emotional attachment people have to place', or the 'sense

\footnotetext{
18 Cresswell (n. 4) 37.

19 Ibid. 48.

20 Ibid. 50.

21 Ibid. 27.

22 M. Heidegger, 'Building Dwelling Thinking' in D. Farrell Krell (ed.),

Basic Writings: Martin Heidegger (revised edn, Routledge, 1993) 343, 350.

23 Cresswell (n. 4) 27.

24 Ibid. 37.

25 Ibid. 46.

$26 \quad$ Ibid. 37.

27 Ibid. 12-13.
} 
of place'. ${ }^{28}$ A third dimension along which places can be studied is a temporal one, since aspects of places change every day, which may or may not change the sense of place; there are 'territorializing forces' that make a place cohere, creating a stronger sense of place, and de-territorializing forces that pull a place apart, making it a different type of place or space. ${ }^{29}$ This dimension is analysed, for example, in the debate on time-space compression (see 5.2 below).

Beyond the distinction between place and space, particularly relevant for the identity-building processes connected to private and public place (see 5 below), manifold geographical insights can inform the debate on privacy in public space on several levels. We start with the descriptive level, looking into issues of context and method.

\section{DESCRIPTIVE LEVEL: QUESTIONS OF CONTEXT AND METHOD}

Although the Newtonian 'neutral container' understanding of space is contested, relevant insights can still be gained from geographers working within this framework to describe and understand places. Traditional regional studies showed the importance of focusing on local particularities and of studying places in context, as co-productions of natural landscape and culture. ${ }^{30}$ Besides, the quantitative turn in geography has shown how geography can benefit from quantitative social-science methods and creative ways of mapping. Scholars such as Berry tried to understand the spatial organization of economy and society using socialscience tools in order to inform public policy and help shape urban justice. ${ }^{31}$ Spatial science, spearheaded by Haggett, shows how human geography can be described on the basis of geometric forms (such as movement, nodes, networks, hierarchies and surfaces) rather than regions or topics. ${ }^{32}$ Similarly, spatial modelling has been greatly advanced by positivist geographers such as Tobler, who introduced maps scaled in travel time or cost rather than distance and other ways of mapping to

28 Ibid. 14, referring to J.A. Agnew, Place and Politics: The Geographical Mediation of State and Society (Allen \& Unwin, 1987).

29 Cresswell (n. 4) 54, referring to M. DeLanda, A New Philosophy of Society: Assemblage Theory and Social Complexity (Continuum, 2006) 12.

30 See Cresswell (n. 4) 31-3.

31 P. Hubbard and R. Kitchin (eds), Key Thinkers on Space and Place (2nd edn, Sage, 2011) 63-7.

32 P. Haggett, Locational Analysis in Human Geography (Arnold, 1965). 
'represent social or demographic reality rather than just the earth's surface', ${ }^{33}$ and Wilson, who laid the groundwork for mathematical models of trip movements in cities, including microsimulation models focusing not on larger areas but on individuals and households. ${ }^{34}$ Although quantitative models might suggest mechanistic or deterministic accounts of people's behaviour in space, Golledge has shown how the methodologically solid approaches of quantitative geography can be combined with a focus on how people perceive and respond to places in different ways, based on the insight 'that not everyone behave[s] in a spatially rational manner'. ${ }^{35}$ Golledge's development of analytical behavioural geography (as opposed to phenomenological streams in behavioural geography) is interesting in demonstrating how people's understanding of space can be studied within an essentially Newtonian conception of space. ${ }^{36}$

From the descriptive level of geography, several insights can inform the debate on privacy in public. First, it is important to study places in context, with their own physical, social and cultural particularities and logic; thus, in line with Nissenbaum's contextual integrity, ${ }^{37}$ privacy in public should be studied concretely and locally. Second, a descriptive approach of what happens in public spaces does not have to be 'neutral' or posit that humans are rational beings-behaviour can be studied in context through the lens of how (different) people perceive public space (differently). Third, urban planning and decision-making about public spaces, which also have to take into account privacy protection (see 5.3 below), can benefit from analytic, social-science-based accounts of how people behave in public spaces and how this varies over time and space, aided by a variety of visualization tools.

\section{SOCIAL-CONSTRUCTIVIST LEVEL: QUESTIONS OF POWER}

Alongside the importance of place as meaningful location and of studying public spaces and places in context, the more abstract concept of space, divided into private and public, holds great value, particularly

\footnotetext{
33 Hubbard and Kitchin (n. 31) 422.

Ibid. 477-81.

Ibid. $186-7$.

Ibid. 187.

37 H. Nissenbaum, Privacy in Context (Stanford University Press, 2010).
} 
for the practice of politics, democracy and power relations. The socialconstructivist perspective, as applied by post-structuralist and radical geographers, sees space as inherently caught up in social relations, where physical spaces and the social life of citizens are shaped together. ${ }^{38}$ It focuses on the many and variegated ways in which spaces (and social life) are made through emergent patterns of use, their individual and social functions, and power relations. ${ }^{39}$ It asks questions such as: how are private and public spaces shaped; who has access to them; what sorts of norms govern them; and how are the actions that develop in it spread across geographical networks of communication? ${ }^{40}$ Such questions tie in with the long-standing interest of social sciences in issues of power. Generally speaking, power comes down to someone being able to get another to do something that the other would not otherwise do; this does not only involve brute force, but also limiting the other's decision-making space (e.g. through agenda-setting) as well as using cultural, institutional and architectural mechanisms that have a disciplining effect. ${ }^{41}$ The construction of (public) space and place demonstrates well how such mechanisms are used in power relations.

\subsection{Public and Private Spaces}

Despite our intuitive understandings of what counts as public or private space (both as abstract spheres or realms of life, and as physical spaces), this distinction is not at all clear-cut. ${ }^{42}$ In fact, the question of precisely where the boundary between public and private should lie is a matter of

38 A. Madanipour, Public and Private Spaces of the City (Routledge, 2003) $2-4$.

R. Koch and A. Latham, 'Rethinking Urban Public Space: Accounts from a Junction in West London' (2011) Transactions of the Institute of British Geographers 515, 517.

40 L.A. Staeheli and D. Mitchell, 'Spaces of Public and Private: Locating Politics' in C. Barnett and M. Low (eds), Spaces of Democracy: Geographical Perspectives on Citizenship, Participation and Representation (Sage, 2004) 152. 41 R.A. Dahl, 'The Concept of Power' (1957) 2 Behavioral Science 201; P. Bachrach and M.S. Baratz, 'Two Faces of Power' (1962) 56 American Political Science Review 947; S. Lukes, Power: a Radical View (2nd edn, Palgrave Macmillan, 2005).

42 'There is no such thing as the public/private distinction': R. Guess, Public Goods, Private Goods (Princeton University Press, 2001) 106, as quoted in J.R. Parkinson, Democracy and Public Space: The Physical Sites of Democratic Performance (Oxford University Press, 2012) 49. 
intense debate. ${ }^{43}$ Some have even claimed that the distinction is becoming increasingly blurred (see 4.2 and 4.3 below), ${ }^{44}$ advocating its dismissal. ${ }^{45}$ Nevertheless, the distinction has proven compelling and enduring. The subdivision of our social world and the spaces we inhabit into public and private spheres-the public/private distinction-is commonly seen as a key feature of how society organizes itself. ${ }^{46}$ The way space is subdivided and the relationship between the public and private spheres in general can serve as a mirror of social relations and particular socio-cultural contexts, representing a (more or less) desired balance between the individual and society. ${ }^{47}$ The public/private distinction is usually presented as two ends of a spectrum, ${ }^{48}$ an approach we will take as well.

In modern usage, 'private sphere' indicates a part of life that is under the control of the individual in a personal capacity, outside public observation and knowledge and outside official or state control. ${ }^{49}$ It follows that private space is an individuated portion of social space, a

43 Weintraub identified four general models through which the concepts of public and private (in the abstract) are often defined in political theory. The first is a liberal-economic model in which publicity is associated with the state and privacy with the market; the second is the republican-virtue model that sees the public sphere as community and citizenship as distinct from the state and the market; the third is a model of sociability in which publicity is defined in terms of self-representation, display and performance; and, finally, a feminist model in which the public refers to the state and economy while the private refers to the domestic and familial; J. Weintraub, 'The Theory and Politics of the Public/ Private Distinction' in J. Weintraub and K. Kumar (eds), Public and Private in Thought and Practice: Perspectives on a Grand Dichotomy (University of Chicago Press, 1995), as stated in Staeheli and Mitchell (n. 40) 150.

44 J. Bethke Elshtain, 'The Displacement of Politics' in Weintraub and Kumar (n. 43) 166; J. Cohen, 'Rethinking Privacy: The Abortion Controversy' in Weintraub and Kumar (n. 43) 133; J. Squires, 'Private Lives, Secluded Places: Privacy as Political Possibility' (1994) Environment and Planning D: Society and Space 387.

45 G. Rose, Feminist Geographies (University of Minnesota Press, 1993); J.K. Gibson-Graham, The End of Capitalism (As We Know It): A Feminist Critique of Political Economy (1st edn, University of Minnesota Press, 1996).

46 Madanipour (n. 38) 1-2; Staeheli and Mitchell (n. 40) 147; B. Fay, Social Theory and Political Practice (Allen and Unwin, 1975).

47 Madanipour (n. 38) 67-8; S. Watson, City Publics: The (Dis)enchantments of Urban Encounters (Routledge, 2006) 159.

48 See, e.g. B.-J. Koops et al., 'A Typology of Privacy' (2017) 38(2)

University of Pennsylvania Journal of International Law 483.

49 Parkinson (n. 42) 50; Staeheli and Mitchell (n. 40) 151. 
space that individuals enclose to control for their exclusive use. ${ }^{50} \mathrm{It}$ provides a physical home for the body with its mental or portable personal spaces. Aside the inner private space of the mind (highly dependent on the physical body to grasp the outer world), lies personal space, the invisible, mobile and subjective space around the body, functioning as the extension of the body. ${ }^{51}$ It includes spaces that are personalized by people who inhabit them (such as apartments, hotel rooms, workplaces, cars, computers and mobile phones) and the processes through which this personalization occurs. ${ }^{52}$ It is 'a social institution in the sense that the observation of personal space depends on the perceived sense of the self and of the appropriate behaviour in public places'. ${ }^{53}$ Thus, personal space can be described as 'a small protective sphere or bubble that an organism maintains between itself and others' ${ }^{54}$ and which individuals carry with them wherever they go. It functions as a regulatory process through which access to a person is controlled, helping to achieve a desired level of privacy. ${ }^{55}$ Such control enables individuals to create a personal environment, a protective layer from social pressures, which enables them to develop a sense of identity, find a location in the social world and develop as an autonomous political subject: ${ }^{56}$

The control of enclosed, private spaces offers the individual an ability to communicate with others through becoming a means of expression of their will, identity and power. It also offers them the ability to be let alone by being protected from the intrusion of others. The establishment of a private sphere offers the individual the ability to regulate the balance of concealment and exposure, the balance of access to oneself and communication with others. ${ }^{57}$

Personal space therefore provides individuals with a place in the world and acts as a barrier that protects and distinguishes individuals from the outside world. Parts of this space are legally protected by the right to

50 Madanipour (n. 38) 68.

51 Ibid. 22; E. Hall, The Hidden Dimension: Man's Use of Space in Public and Private (Bodley Head, 1966).

52 R. Sommer, Personal Space: The Behavioural Basis of Design (PrenticeHall, 1969) viii; Parkinson (n. 42) 54.

53 Madanipour (n. 38) 31.

54 Hall (n. 51) 112.

55 I. Altman, The Environment and Social Behaviour: Privacy, Personal

Space, Territory, Crowding (Brooks/Cole, 1975) 3.

56 Elshtain (n. 44) 180.

57 Madanipour (n. 38) 68. 
privacy in various forms (such as protection of the home, communication, personality and personal data), as seen in many international human rights instruments, national constitutions and other laws around the world. ${ }^{58}$

At the other side of the spectrum, we find public space. Public space has traditionally been seen as a shared space that serves as a place to gather and meet both friends and strangers, where the term 'public' connotes the idea that such settings (and activities therein) are accessible to everyone. ${ }^{59}$ They are generally places outside the boundaries of individual or small-group control and are used for a variety of functional and symbolic purposes. ${ }^{60}$ Accordingly, Altman described public space as a physical space to which almost anyone has free access and occupancy rights on a temporary basis. ${ }^{61}$ Such space is important because it provides a physical space for interpersonal communication and social encounters, but also because it represents the stage upon which communal life unfolds, where individuals, groups and crowds become political subjects. ${ }^{62}$ In that sense, public space is closely connected to the concept of the public sphere, which provides individuals an opportunity to engage in political participation through discussion, forming opinions and building consensus, as well as engaging in collective political action to pursue mutual goals. ${ }^{63}$ Thus, public space plays a powerful role in the social and political activities involved in the 'making of the public(s)' that constitutes the public sphere by providing individuals and groups a material

58 Koops et al. (n. 48).

59 Altman and Zube (n. 14) 1; Madanipour (n. 38) 111.

60 Madanipour (n. 38) 112-13.

61 Altman (n. 55) 118; similarly E. Goffman, The Presentation of Self in Everyday life (Allen Lane, 1969).

62 S. Carr, M. Francis, L.G. Rivlin and A.M. Stone, Public Space (2nd edn, Cambridge University Press, 1995).

63 J. Habermas, The Structural Transformation of the Public Sphere: An Inquiry into a Category of Bourgeois Society (MIT Press, 1991); H. Arendt, The Human Condition (University of Chicago Press, 1998); S. Benhabib, Democracy and Difference: Contesting Boundaries of the Political (Princeton University Press, 1996). Madanipour (n. 38) 236 defines the public sphere as 'a collection of material and institutional common and inclusive spaces, in which the members of society meet, to share experiences, to present and exchange symbols and create meaning, and to deal with collective self-rule through seeking consensus as well as exploring difference'. 
space to engage in political participation. ${ }^{64}$ This involves values of plurality, openness and social learning, ${ }^{65}$ as well as activities such as making claims; achieving visibility and recognition; influencing public opinion; establishing legitimacy; contesting the conception of the public; renegotiating social and political rights; and (group) identity formation. ${ }^{66}$ Public space hence features personal rights that are both politically and spatially grounded, including the right to representation, assembly and freedom of action in urban open spaces. ${ }^{67}$

Fraser has criticized the singular universal public sphere as conceptualized by Habermas, arguing that it needs to be replaced with a theory of multiple contending, often mutually exclusive, public spheres. ${ }^{68}$ In that sense, public space is a site of contention and instability, the meaning of which always involves a struggle. ${ }^{69}$ Hence, public spaces are sites of heterogeneity and interaction that educate city-dwellers about the 'other'70 since they encourage mingling and encounters between people of different classes, races, ages, religions, ideologies and cultures. ${ }^{71}$ This means that public spaces of democratic societies have a processual and fluidic character: they are constructions to be maintained and repaired as the collective interests are defined and contested. ${ }^{72}$

64 'Democracy is "the politics of the street", which necessitates a material grounding in public space'; S. Springer, 'Public Space as Emancipation: Meditations on Anarchism, Radical Democracy, Neoliberalism and Violence' (2011) 43 Antipode 525, 533; D. Mitchell, The Right to the City (Guilford Press, 2003);

I.M. Young, Inclusion and Democracy (Oxford University Press, 2000).

65 E.S. Ruppert, 'Rights to Public Space: Regulatory Reconfigurations of Liberty' (2006) 27 Urban Geography 271, 277.

66 Ruppert (n. 65) 281-2.

67 H. Lefebvre, The Production of Space (Wiley-Blackwell, 1991); Mitchell (n. 64).

68 N. Fraser, 'Rethinking the Public Sphere: A Contribution to the Critique of Actually Existing Democracy' (1990) Social Text 56.

69 This connects to the concept of agonism, which refers to the idea that conflict cannot and should not be eradicated in democratic societies; see Springer (n. 64) 525, 530; Mitchell (n. 64) 18.

70 J. Németh and J. Hollander, 'Security Zones and New York City's Shrinking Public Space' (2010) 34 International Journal of Urban and Regional Research 20.

71 Ruppert (n. 65) 273; D. Harvey, 'The Right to the City' (2008) $53 \mathrm{New}$ Left Review 23, available at https://newleftreview.org/II/53/david-harvey-theright-to-the-city (accessed 26 September 2016).

72 Springer (n. 64) 542; what Agamben called 'a means without end', in G. Agamben, Means Without End: Notes on Politics (University of Minnesota Press, 2000); Watson (n. 47) 7. 
Despite the relatively clear division between private and public space as presented above, the relationship between them is complex, as they are mutually constructed. ${ }^{73}$ In between the two realms lies a series of gradations- 'liminal' spaces - where the private and the public collide. ${ }^{74}$ Rather than being separated, the two are intertwined and interdependent. They have a symbiotic relationship: public and private spaces (along with publicness and privacy) are defined in relation to each other, so that the relationship is 'multivalent and may shift over time and across different settings for different social groups' ${ }^{75}$ While the public sphere has been theorized as the space of politics, it is a space that is also constituted in and through privacy. ${ }^{76}$ As Elshtein put it:

[T] he public world itself must nurture and sustain a set of ethical imperatives that include a commitment to preserve, protect, and defend human beings in their capacities as private persons, as well as to encourage and enable men and women alike to partake in the practical activity of politics. Such an ideal seeks to keep alive rather than to eliminate tensions between diverse spheres and competing values and purposes ... Only in the space opened up by the ongoing choreography of [public and private] can politics exist—or at least any politics that deserves to be called democratic. ${ }^{77}$

Since the public and private are interdependent, shifting the boundaries in the private sphere causes a rearrangement of the spaces of publicness, and vice versa. ${ }^{78}$ The resulting picture is therefore one of complex and closely connected spheres and spaces that have at times a tense relationship with each other and, in any case, are always changing and evolving.

73 Watson (n. 47); Madanipour (n. 38) 171.

74 Parkinson (n. 42) 53; N. Blomley, 'Flowers in a Bathtub: Boundary Crossings at the Public-Private Divide' (2005) 36 Geoforum 281, 294.

75 Benhabib (n. 63); Staeheli and Mitchell (n. 40) 149-50.

76 Staeheli and Mitchell (n. 40) 151.

77 Elshtain (n. 44) 180 (original emphasis).

78 Similarly, Jacobson argues that human beings are not first or most originally 'public' beings; rather, we must develop the behaviours and attitudes necessary for citizenship. This is something we can only do by emerging from our familiar, personal territories-our homes; K. Jacobson, 'The Experience of Home and the Space of Citizenship' (2010) 48 Southern Journal of Philosophy 219. 


\subsection{Privatization of Space}

Particularly since the 1990s, the ongoing transformation of urban public space, including shifts in design, management, financing, and the proliferation of (both physical and digital) surveillance, has emerged as a key focus of geographical-particularly post-structuralist and Marxistconcern. Building on the political notion of public space and its value for the practice of democracy, many geographers have (usually critically) observed two trends: the privatization and securitization of public space.

Privatization of public space here refers to the atrophying of the public sphere as a result of the domination of private, neo-liberal interests over the provision, regulation and maintenance of public space. ${ }^{79}$ Since the end of the 1980s, for a number of socio-political and budgetary reasons, many states (especially in North America and Western Europe) have ceded many of their core functions concerning the regulation of public space to local governments and, increasingly, the private sector. ${ }^{80}$ This involves private construction, funding, management and security of public spaces, which, so many have argued, transforms these into privately owned public spaces (POPs) or semi- or quasi-public spaces that look public but are not (in the sense that the rights connected to public space are severely curtailed). ${ }^{81}$ Cities are now rich in new types of public-seeming spaces, such as shopping malls, corporate open spaces (plazas, parks, gardens), business and innovation districts (BIDs), and gated communities. ${ }^{82}$ In contemporary public and quasi-public spaces, an extending array of activities is being forbidden: taking pictures without a

79 Mitchell (n. 64); E. Soja, ThirdSpace (Blackwell, 1996); M. Sorkin (ed.), Variations on a Theme Park: The New American City and the End of Public Space (Hill and Wang, 1992); M. Kohn, Brave New Neighborhoods: The Privatization of Public Space (Routledge, 2004).

80 R. Van Melik, I. Van Aalst and J. Van Weesep, 'Fear and Fantasy in the Public Domain: The Development of Secured and Themed Urban Space' (2007) 12 Journal of Urban Design 25; A. Loukaitou-Sideris, 'Privatisation of Public Open Space: The Los Angeles Experience' (1993) 64 Town Planning Review 139.

81 Mitchell (n. 64); Harvey (n. 71).

82 For more on BIDs, see M. Steel and M. Symes, 'The Privatisation of Public Space? The American Experience of Business Improvement Districts and their Relationship to Local Governance' (2005) 31 Local Government Studies 321; also see T. Weaver, 'The Privatization of Public Space: The New Enclosures' (2014) Annual Meeting of the American Political Science Association, 28-31 August, available at http://papers.ssrn.com/sol3/papers.cfm?abstract_id= 2454138 (accessed 26 September 2016). 
permit; giving speeches; sleeping rough; drinking a beer on the grass; or dissenting in a variety of peaceful ways. ${ }^{83}$ Kohn argues that due to the growing phenomenon of private government, public space is disappearing and public life (including democratic practices) is undermined. ${ }^{84}$

The creation of new types of public space seems to be driven by the desire to ensure that spaces are safe, lucrative, predictable and, all in all, tightly defined. Corporate producers of space seem to see the public as a homogeneous mass and a passive market receptive to commercial consumption of the city. ${ }^{85}$ Consequently, social action in such spaces is tightly scripted and prescribed, and behaviour becomes standardized. ${ }^{86}$ This results in significant restrictions of behaviour, with rules that secure the boundaries of acceptable behaviour within a space now increasingly governed by private entities controlling POPs. ${ }^{87}$ This also implies a loss of contextualization and leads to what Sorkin calls 'a city without a place attached to it' 88 - a city comprised of 'themed spaces'. Such spaces are departicularized, no longer acting as sites of community and human connection, and increasingly look alike (shopping malls or city squares in Rotterdam and New York are strikingly similar); they become "nonplaces'. ${ }^{89}$ They practice a form of management and control of flows of populations, making public space (feel) safer in order to maximize the number of visitors, to attract more advertising, to stimulate consumption and to facilitate spending. ${ }^{90}$ Such a city, with its new types of privatized

83 Weaver (n. 82); G. van Eijk, 'Exclusionary Policies are Not Just about the "Neoliberal City": A Critique of Theories of Urban Revanchism and the Case of Rotterdam' (2010) 34 International Journal of Urban and Regional Research 820; B.L. Garrett, 'The privatisation of cities' public spaces is escalating: it is time to take a stand', Guardian, 4 August 2015, available at www.the guardian.com/cities/2015/aug/04/pops-privately-owned-public-space-cities-directaction (accessed 26 September 2016).

84 Kohn (n. 79) 3.

85 H. Silver, 'Editorial: The Centrality of Public Space' (2014) 13 City and Community 1, 3 .

86 D.J. Madden, 'Revisiting the End of Public Space: Assembling the Public in an Urban Park' (2010) 9 City and Community 187.

87 Weaver (n. 82) 3.

88 Sorkin (n. 79) xi.

89 M. Augé, Non-Places: Introduction to an Anthropology of Supermodernity (J. Howe (trans.), Verso, 1995).

90 B.E. Harcourt, Digital Security in the Expository Society: Spectacle, Surveillance, and Exhibition in the Neoliberal Age of Big Data, Columbia Public Law Research Paper (2014), available at http://papers.ssrn.com/sol3/papers. cfm?abstract_id=2455223 (accessed 26 September 2016). 
public space, is closely connected to the second trend geographers have observed: the securitization of public space.

\subsection{Boundary Management, Access Control and Securitization}

The securitization of public space refers to the decline of openness and accessibility of public space due to the exercise of political power by both state and private actors who are increasing their control and policing of public space. ${ }^{91}$ A growing range of conduct, activities, political practices and wide-ranging groups of 'undesirables' are being excluded not only from privately-owned but also from state-owned public spaces. ${ }^{92}$ Hence, public space (along with social and political activities that make up public life) is constituted not only through ownership but also through a wide range of regulatory practices, such as laws, regulations, urban design, surveillance and policing.

Despite the political discourse on public space that emphasizes its accessibility and openness, public space is neither free and democratic nor repressed and controlled-it is both at the same time: "[i]t is simultaneously a space of political struggle and expression and of repression and control' .93 Thus, public space has an essentially two-sided character, which has assumed widely varying historical forms. ${ }^{94}$ While exclusion and repression are clearly not new phenomena, we are arguably witnessing new forms of exclusion and control in public space. These are based on a changing conception of the public and a reconfiguration of liberty that exclude certain non-criminal conduct, activities, groups and political practices and that are increasingly based on preconceptions, prejudices, and fear of potential harm rather than real danger. ${ }^{95}$ In the securitized city premised on a need for surveillance and control over

91 Z. Neal, 'Seeking Common Ground: Three Perspectives on Public Space' (2010) Proceedings of the Institution of Civil Engineers, Urban Design and Planning 1, 4; Mitchell (n. 64).

92 Ruppert (n. 65) 274.

93 L. Lees, 'Urban Renaissance and the Street: Spaces of Control and Contestation' in N.R. Fyfe, Images of the Street: Planning, Identity and Control in Public Space (Routledge, 1998) 238, quoted in Ruppert (n. 65) 189.

94 J. Dixon, M. Levine and R. McAuley, 'Locating Impropriety: Street Drinking, Moral Order, and the Ideological Dilemma of Public Space' (2006) Political Psychology 187, 190.

95 A. von Hirsch and C. Shearing, 'Exclusion from Public Space' (1999) Workshop on Situational Crime Prevention: Ethics and Social Context, Fitzwilliam College, Cambridge, available at http://papers.ssrn.com/sol3/papers. cfm?abstract_id=2799204 (accessed 26 September 2016). 
behaviour, public space is secured from the public rather than for it. ${ }^{96}$ This has led some to declare, rather dramatically, the "end of public space', ${ }^{97}$ and the 'militarization' 98 or 'disneyfication'99 of public space. However, such claims have also been criticized for having an idealized and nostalgic view of the golden days of public space, and for presenting too bleak a view of public space as a site of contention where people are excluded and dominated and as an institution that is disappearing as quickly as democracy itself. Some geographers, such as Jacobs and Whyte, hold a relatively optimistic approach to public space, which recognizes the evolution of public spaces, where old forms may disappear but new forms are being created, and treats conflict in public space as a challenge to be overcome by improved design. ${ }^{100}$

Several mechanisms of control have been developed recently. ${ }^{101}$ The simplest form is found in 'sadistic street furniture', such as barrel-shaped benches, sprinklers, spikes and decorative enclosures, designed to keep homeless and youth away from specific areas. ${ }^{102}$ More recently, with the devolution of power from the state to local governments, attempts to create 'security zones' 103 can be seen, accompanied by (a resurgence of) punitive models of 'law and order' governance 104 that include zerotolerance policing, widespread surveillance and new public nuisance laws with legal instruments such as anti-social behaviour orders (ASBOs) and public space protection orders (PSPOs). PSPOs, for example, provide local councils with broad powers to criminalize behaviour that is not normally considered criminal. PSPOs are also not directed at individuals; rather, they are geographically defined, making predefined activities within a mapped area prosecutable. Such regulation of public space

96 As Larry Vale put it, referenced in P. Marcuse, 'Security or Safety in Cities? The Threat of Terrorism after 9/11' (2006) 30 International Journal of Urban and Regional Research 919.

97 Mitchell (n. 64).

98 M. Davis, City of Quartz: Excavating the Future in Los Angeles (Verso, 2006).

99 Sorkin (n. 79).

100 J. Jacobs, The Death and Life of Great American Cities (Random House, 1961); W.H. Whyte, The Social Life of Small Urban Spaces (Project for Public Spaces, 2001).

101 Neal (n. 91) 4.

102 Davis (n. 98) 226.

103 Also called 'security bubbles'; see Németh and Hollander (n. 70); Mitchell (n. 64) 43-51.

104 A.P. Brown, 'Anti-Social Behaviour, Crime Control and Social Control' (2004) 43 Harvard Journal of Criminal Justice 203, 204. 
discourages a wide range of spirited expression (labelled as 'anti-social' or 'escalating behaviour') and encourages stereotyped behaviour and 'social neutrality' in general. Such practices are a form of security that target what or whom is deemed to cause fear, including panhandlers, squeegee cleaners, prostitutes, addicts, rowdy teenagers, loiterers, the mentally disturbed and strangers, along with boom-box cars, public drunkenness, reckless cycling and graffiti. ${ }^{105}$ Prohibitions of conduct are often based on the proposition that order is only possible by excluding certain people and conduct. ${ }^{106}$ Although the basis for this exclusion is presented as natural or obvious, it is founded on interpretations of what constitutes violence or disorder. Today an incredibly wide array of people and activities are seen as not belonging in (certain parts of) public space. The promise of safety, security and order can hence quickly lead to discrimination, exclusion, displacement or domination. ${ }^{107}$

Security practices in the controlled city do not seek to modify behaviour but, rather, use space in a territorial way to exclude behaviour that is threatening to its imagined values. ${ }^{108}$ As Foucault has observed, space is fundamental to the use of power. ${ }^{109}$ The purpose of securing a particular territory is to produce a place that is different from those around it. Consequently, as Zedner remarks, a complex geography of security is emerging from these practices that encompasses different " "patchworks", "quilts", "bubbles", "corridors", "mosaics", "webs", "networks", and "nodes" 110 of secure spaces that extend across different urban spaces in different ways. ${ }^{111}$ In such a controlled city, space usage (varied activities taking place in public) is by permit and not by right, and rights can best be exercised at home, in private, effectively discouraging political engagement. ${ }^{112}$ Some have therefore argued that the privatization and securitization of private space have reconfigured the

105 R. Yarwood and T. Paasche, 'The Relational Geographies of Policing and Security' (2015) 9 Geography Compass 362.

106 Mitchell (n. 64).

107 Ruppert (n. 65) 191.

108 Yarwood and Paasche (n. 105) 364.

109 S. Elden, 'Politics, Philosophy, Geography: Henri Lefebvre in Recent Anglo-American Scholarship' (2001) 33 Antipode 152; as referred to in Hubbard and Kitchin (n. 7) 165.

110 L. Zedner, Security (Taylor \& Francis, 2009) 61.

111 For more on US 'bubble laws' regulating the actions of protesters within certain distances of (abortion) clinics and homes (also establishing moving bubbles around patrons and employees entering clinics), see Mitchell (n. 64) 42-51.

112 R. Sennett, The Fall of Public Man (1st edn, Knopf, 1977). 
relations between public and private in ways that may not have been intended. ${ }^{113}$ Elshtain argues that '[i]f all conceptual boundaries are blurred and all distinctions between public and private are eliminated, then, by definition, no politics can exist'. ${ }^{114}$ The main issue here concerns the extent to which the liberties connected to public space, including right to representation, assembly and freedom of action in urban open spaces, can be safeguarded when ownership and management is distanced from democratic forms of control. ${ }^{115}$

\subsection{Implications for Privacy in Public}

Although it is impossible to define public space on the basis of ownership or even access control, many laws simply consider diverse types of state, collective or private property with regulated access (for instance, demanding payment for access) as public spaces. ${ }^{116}$ However, as (post-)structuralist geographers have shown, the division of the social world into public and private is not a natural division; rather, it is an expression of power. In view of the privatization and securitization of public space and the implications of this for our public and private lives, regulators should take notice of the fluid and increasingly blurred boundary between public and private space. If cities are becoming riddled with privately owned and managed public spaces, such as corporate parks and squares, where access and activities are tightly regulated in line with private interests, the law should make it clearer that liberties connected to public space, such as the right to representation, assembly and freedom of action in open spaces, are protected in these new types of public space as well. Moreover, since the public and the private spheres are interdependent and establish each other, the implications of privatization and securitization of public space for privacy also require reflection. Public spaces should not be conflated with public actions, nor should private spaces be conflated with private actions. Certain private actions are, and always have been, performed in public, protected by the layer of 'personal space' that people carry with them when moving around in public spaces. With the proliferation of security measures, including digital surveillance technologies, in public space, parts of our private lives that take place in public space are becoming endangered. Regulators should take notice of this and provide for

\footnotetext{
113 Elshtain (n. 44); Cohen (n. 44); Squires (n. 44).

114 Elshtain (n. 44) 170, quoted in Staeheli and Mitchell (n. 40) 149.

115 Koch and Latham (n. 39) 521.

116 Ruppert (n. 65).
} 
adequate protection of privacy in public, in order to preserve a reasonable balance between private and public space. This argument is strengthened by another insight from geography, namely the role of place in identity building.

\section{PHENOMENOLOGICAL LEVEL: QUESTIONS OF IDENTITY}

\subsection{Place and Identity}

A major topos in human geography is identity. Rather than the traditional interest in the identity of places-the 'genius loci' - this refers to how people construct and enact their identities in spatial settings. Places 'are fundamental in expressing a sense of belonging for those who live in them, and are seen as providing a locus for identity'.117 Given that identity is often formed through narratives, ${ }^{118}$ making sense of ourselves also involves mapping the world in which we live. Narration is a form of mapping, through which we try to re-establish our sense of place in the world (sometimes the very act of telling a story is also a process of producing a map; this operates in both directions: storytelling involves mapping, but a map also tells a story). ${ }^{119}$

In privacy theory, Agre conceptualizes privacy as identity construction: 'the right to privacy is the freedom from unreasonable constraints on the construction of one's own identity'.120 Geographers, also drawing from other disciplines, have analysed and theorized how the construction of identity is influenced by spatial constraints, but also how it affects the construction of place. This has been explored particularly in relation to issues of culture, race and gender. Cultural identity is socially and spatially constructed, in a process of co-production. Jackson has, for example, analysed how 'subcultural groups fashion identity through appropriation and transformation' of artefacts. Through a geography of cultural materialism, cultures can be studied as 'maps of meaning

\footnotetext{
117 Hubbard and Kitchin (n. 7) 6.

118 See e.g. M.R. Somers, 'The Narrative Constitution of Identity: A Relational and Network Approach' (1994) 23 Theory and Society 605.

119 Tally, Jr (n. 6) 46.

120 P.E. Agre, 'Introduction' in P.E. Agre and M. Rotenberg (eds), Technology and Privacy: The New Landscape (MIT Press, 1998) 7.
} 
through which the world is made intelligible'.121 In a similar vein, Butler's work on gender and identity has influenced geographers' study of identities and bodies in relation to their spatiality, for example inspiring studies that argue 'that bodily performances [such as the Rio Carnival] themselves constitute or (re)produce space'. ${ }^{122}$ Scholars such as Sibley, in psychoanalytically informed studies of self-construction, argue that boundary management of the self may also be connected to a deeply engrained desire for cleanliness and purity, leading to marginalizing minority groups as 'polluting' the environment and the 'purification of social space'. ${ }^{123}$ This also connects, for instance, to Jackson's work on patterns of social interaction, segregation and ghettoization. ${ }^{124}$

In a different line of research, geography has engaged with conceptualizing the home, as the primary place where identity may be formed. 'Home is where you can be yourself. In this sense home acts as a kind of metaphor for place in general.' ${ }^{125}$ The home can be connected to Heidegger's notion of 'dwelling as the ideal kind of authentic existence' 126 and seen as a place of intimate human relationships, family life, and care for the sick and injured. ${ }^{127}$ Bachelard's conception of the home as a place of 'attachment that is native in some way to the primary function of inhabiting' - arguing that this is formed through images and memories-also intrinsically connects the home to identity construction. ${ }^{128}$ Notably, the (house as) home is a historically contingent form of social organization, having evolved over the past centuries particularly as a construction to house the nuclear family-through social changes in households, its function and shape are now shifting. ${ }^{129}$ Indeed, the home is not an independent space: it takes meaning only through the spaces it

121 P. Jackson, Maps of Meaning (Unwin Hyman, 1989) 2 (emphasis in original), quoted in Hubbard and Kitchin (n. 31) 259.

122 Hubbard and Kitchin (n. 31) 86.

123 D. Sibley, 'Survey 13: Purification of Space' (1988) 6 Environment and Planning D: Society and Space 409.

124 Hubbard and Kitchin (n. 31) 257-8.

125 Cresswell (n. 4) 39. Cf. Jacobson (n. 78) 223; K. Jacobson, 'A Developed Nature: A Phenomenological Account of the Experience of Home' (2009) 42 Continental Philosophy Review 355.

126 Cresswell (n. 4) 39.

127 Tuan (n. 13) 137-8.

128 G. Bachelard, The Poetics of Space: The Classic Look at How We Experience Intimate Places (M. Jolas (trans.), first published 1964, Beacon Press, 1994) 4.

129 Madanipour (n. 38) 106. 
is not: the home is "co-constituted as home by encountering an alienworld'. ${ }^{130}$ Moreover, several feminists have contested the 'rosy view of home' and argued it to be a central site of oppression of women, although others emphasize the home's relative freedom from oppression that marginalized groups, such as black people, suffer outside. ${ }^{131}$ The home is thus 'a particular kind of safe place where (some) people are relatively free to forge their own identities'. ${ }^{132}$ However, also public places can have the same function, in light of increasing mobility and what geographers tend to refer to as 'time-space compression', that is, the processes by which distances are crossed more rapidly by people, goods or information. ${ }^{133}$

\subsection{Mobility, Time-Space Compression and De/Re-Territorialization}

The increasing mobility of people, things and capital in the past decades and the associated process of globalization have had an obvious impact on space and place. The blurring and collapsing of spatial barriers through, for instance, air travel, telecommunications, and the Internet, are transforming our experience of space. ${ }^{134}$ Thus, Castells has argued, in the network society, the traditional 'space of places' has given way to a 'space of flows', 135 and the creation of places becomes more dynamic than envisioned in Tuan's emphasis on stasis. The implications of this are manifold. Some have highlighted, for example, how globalization involves the creation of 'non-places': fleeting sites where history and tradition matter little, such as highways, airports and supermarkets. ${ }^{136}$ This requires thinking of space and place not in terms of boundaries and roots but from the perspective of movement and routes. ${ }^{137}$ Thus, for instance, identities can also be construed 'in cosmopolitan forms of mobility rather than in stable and bounded places'. ${ }^{138}$ Bauman argues

130 A.J. Steinbock, Home and Beyond: Generative Phenomenology after Husserl (Northwestern University Press, 1995) 182.

131 Cresswell (n. 4) 40-1.

132 Ibid. 41.

133 B. Warf, 'Teaching Time-Space Compression' (2011) 35 Journal of Geography in Higher Education 143, 144.

134 Tally, Jr (n. 6) 41; J. May and N. Thrift, 'Introduction' in J. May and

N. Thrift (eds), TimeSpace: Geographies of Temporality (Routledge, 2001).

135 M. Castells, The Rise of the Network Society (Blackwell, 2000) ch. 6.

136 Augé (n. 89) 78.

137 Cresswell (n. 4) 78.

138 Ibid. 81. 
that globalization and deterritorialization go together with reterritorialization of the nation-state-thus, 'glocalization' - but that the resulting social change empowers the globals with freedom of movement and disempowers the static locals. ${ }^{139}$ However, although cosmopolitans are often associated with the travelling rich and contrasted with the local poor, in reality the poor are actually often more mobile and multilingual, working as taxi-drivers or hotel staff in far-away countries; moreover, cosmopolitans depend on locals and locally diverse cultures to enjoy their travels. ${ }^{140}$ All of this shows the ongoing importance of place in a globalizing world.

Others have debated the implications of the time-space compression that results from mobility and globalization. Cresswell contrasts Harvey's and Massey's analyses of how people re-invent place in a globalizing world. ${ }^{141}$ Harvey emphasizes the power-play and conservatism in people's efforts to re-create a sense of place to resist the forces of global capitalism and migration, showing how dominant groups in gated communities monopolize the meaning attached to a local neighbourhood to the exclusion of 'others'. ${ }^{142}$ Massey agrees that the desire for rootedness and creating a sense of place to provide stability in a moving world can be reactionary and 'a form of romanticized escapism', ${ }^{143}$ but argues that this does not have to be the case. Time-space compression does not necessarily lead to feelings of insecurity, but can also lead to a 'progressive concept of place'. This is characterized by place as process, involving multiple and diverse identities, defined by interactions with the outside rather than by an intrinsic unitary identity associated with the place. Places therefore are not settled, but continuously demand negotiation with the 'throwntogetherness' that characterizes today's places in a progressive reading. ${ }^{144}$ However, the 'politics of place in a globalized world' are even more complex than Harvey's and Massey's analyses suggest-people seek and experience rootedness and boundaries in relation to the outside and to diversity in different, complicated ways. ${ }^{145}$

139 Hubbard and Kitchin (n. 31) 52; see Z. Bauman, 'On Glocalization: Or Globalization for Some, Localization for Some Others' (1998) 54 Thesis Eleven 37.

140 Cresswell (n. 4) 82-3.

141 Ibid. 88-114.

142 D. Harvey, Justice, Nature and the Geography of Difference (Blackwell Publishers, 1996).

143 D. Massey, Space, Place, and Gender (Polity Press, 1994) 151.

144 Ibid. 141-56.

145 Cresswell (n. 4) 113. 
What is clear, in any case, is that place is now less associated with a particular location where people feel rooted. Malcolm McCullough captures this eloquently:

At least to the more mobile and networked of us, place has become less about our origins on some singular piece of blood soil, and more about forming connections with the many sites in our lives. Place [has] become less an absolute location ... and more a relative state of mind that one gets into by playing one's boundaries and networks. ${ }^{146}$

McCullough ties in to another strand in the time-space compression debate: the role of the Internet and new media. While in its early days, the Internet was conceptualized as a separate, online space existing in parallel to the offline world, scholars are now emphasizing the enmeshing of the virtual and the physical environment. ${ }^{147}$ Indeed, "the word "cyberspace" now sounds dated' 148 as the "world of the virtual has become place-oriented'. ${ }^{149}$ McCullough deconstructs the argument that 'the word "media" implies ... disembodiment ... and that implies trouble for space and place as we know them', by showing how media increasingly have a locative component, so that 'media become embodied in access, spatial in operations, and place based in content'. ${ }^{150}$ Locative media, such as GPS-equipped devices and geo-location-based services, form another example of reterritorialization in a globalizing world. The result is that 'the physical, tangible world combines with virtually accessible information and creates not a fixed setting for interaction, but a lived, fluid, and subjective space, shaped by space, time, and information'. ${ }^{151}$ However, as our attention in space is focused through digital media-filtered information rather than through physical cues in urban landscapes and architecture, the addition of location-based information alters our experience of place. The filtering, for instance in Google Maps, depends on

146 M. McCullough, 'On the Urbanism of Locative Media' (2006) 18 Places 26, 29.

147 See e.g. R. Kitchin and M. Dodge, Code/Space: Software and Everyday Life (MIT Press, 2011). This also has an impact on the public sphere, see M. Castells, 'The New Public Sphere: Global Civil Society, Communication Networks, and Global Governance' (2008) 616 Annals of the American Academy of Political and Social Science 78.

148 McCullough (n. 146) 26.

149 Cresswell (n. 4) 144.

150 McCullough (n. 146) 26.

151 M.A. Zook and M. Graham, 'Mapping DigiPlace: Geocoded Internet Data and the Representation of Place' (2007) 34 Environment and Planning B: Planning and Design 466, 468. 
economic and political interests, but this is not visible to most (noncritical) users who take location-based information at face value. And this 'lack of visibility in software can easily translate into a lack of visibility in hard-where (place)'.152

\subsection{Implications for Privacy in Public}

Geographers have shown how place and identity are closely intertwined, in a process of co-production. 'Place is the raw material for the creative production of identity rather than an a priori label of identity.' ${ }^{153}$ Although the home may still be seen as a key place where identity can be constructed, with time-space compression and increased mobility, the experience of place may still be rooted and localized, but in much more fluid, diverse and networked ways than being attached to a single place of dwelling. The narratives people use to understand themselves in the world, which are constitutive of their identity, are nowadays associated with multiple places and flows, and thus equally formed through people's experiences in public places as they are through living at home. Moreover, the home has never been completely private, but is 'in reality an interdependent, interpersonal sphere in which shades of privacy and publicness existed'; it mediates between the public and the private. ${ }^{154}$ Yet the law continues to assume a fixed and clear-cut distinction between private space and private property (which carries a strong reasonable expectation of privacy, besides a strong property interest in common-law systems) and public space (carrying far less reasonable expectation of privacy). ${ }^{155}$ The mobile nature of identity construction in a space of flows suggests that privacy, as freedom to shape one's identity, also requires protection in public. Moreover, reterritorialization and the enmeshing of virtual and physical space imply a need to reflect on how the embodied experience of place is influenced by digital information flows projected onto and interacting with physical space. This challenge is starting to be taken up, ${ }^{156}$ but requires considerable further study, not the least in relation to concrete places and practices.

\footnotetext{
152 Ibid. 479.

153 Cresswell (n. 4) 71.

154 Madanipour (n. 38) 107.

155 Cf. Blomley (n. 74).

156 E.g. J.E. Cohen, Configuring the Networked Self: Law, Code, and the Play of Everyday Practice (Yale University Press, 2012).
} 


\section{CONCLUSION}

Following the themes of context, power and identity, we have discussed how insights from human geography can inform the debate on privacy in public. Studying concrete practices of place-making helps to understand the complex nature of 'public space': it features multiple places, actors and flows that together shape the uses and experiences of space, in contexts where power relations, privatization and securitization, and time-space compression fundamentally affect people's sense of place, including but not limited to minorities who are at risk of feeling, or being made to feel, out of place. It is interesting to note that many of these themes are also being analysed within surveillance studies ${ }^{157}$ (something which invites further study), yet such analyses have yet to penetrate into the mainstream regulatory debate on privacy in public.

Public space consists of many places. Places in public space are not given but constructed by people, often on the basis of power relations, and this has significant consequences for individuals' sense of place. As people build their identities in relation to places, particularly places where they feel at home or 'in place', identity and place construction need to be considered jointly as being co-produced. It is here that the law's application of a clear boundary between public and private space becomes salient and problematic. The public/private space distinction (in law) mirrors the insight of the relational nature of space: a space only gets meaning in context (in relation to the people and things in it) and in relation to its outside; 'home' and 'public space' are therefore two sides of a coin. However, being-at-home is not only relevant 'at home' in the sense of a fenced-off building that is private space; it can take place wherever people may experience being 'in place'. (Indeed, as the great philosopher Sendak has illustrated, leaving the most traditionally private space, one's bedroom, to venture into public space can be a remarkably rewarding type of identity-building, and being-at-home can equally well be experienced 'where the wild things are' as in the safety of one's bedroom. ${ }^{158}$ ) Moreover, the division of space into public and private parts is a construct, which is continuously changing. Thus, private life cannot be equated with private space: there is private life in public space and public life in private space as well. We should also realize that the

157 M. Galič, T. Timan and B.-J. Koops, 'Bentham, Deleuze and Beyond: An Overview of Surveillance Theories from the Panopticon to Participation' (2016) 29 Philosophy and Technology, DOI 10.1007/s13347-016-0219-1.

158 M. Sendak, Where the Wild Things Are (Harper \& Row, 1963). 
house-as-home is just as much a historically contingent and constructed place as are mushrooming privately owned public spaces.

All of this suggests that privacy as the freedom to develop one's identity should be analysed in relation to place in all the richness, variation and complexity that place entails, which goes far beyond a simplistic notion of a 'private place', epitomized by the home, that, in a legal and regulatory context, is all too often associated with privacy. Identities connected to being-at-home are also constructed in public places, in movement, and in physical-digital networked spaces. Furthermore, due to the proliferation of security measures, including digital surveillance technologies, in public space (physical and digital), parts of our private life that are enacted in public are becoming endangered. Privacy therefore requires protection in public space. What kind and level of protection that should be depends on concrete situations and contexts - one cannot give universal rules for 'privacy in public'.

Besides lessons for the debate on privacy in public, we think that human geography can be more generally relevant to legal and regulatory scholarship. This is acknowledged in the emerging field of legal geography, which tries to integrate insights from law and geography in interdisciplinary analyses. While a considerable part of legal geography is focused on heightening understanding of the law within geographic debates, we think the reverse is equally important, and we hope that this chapter will contribute to heightening awareness of geographic concepts and insights within legal and regulatory debates. 